\title{
IMPROVING THE PERFORMANCE OF CELLULAR MANUFACTURING BY A DYNAMIC PART ASSIGNMENT APPROACH
}

\author{
HAMID SEIFODDINI ${ }^{1}$ and MANOOCHER DJASSEMI ${ }^{2}$ \\ 'Industrial and Manufacturing Engineering Department, The University of Wisconsin-Milwaukee, \\ Milwauki, WI 53201, U.S.A. \\ ${ }^{2}$ Industrial Studies Department, The University of Wisconsin-Platteville, Platteville, WI 53818, U.S.A.
}

\begin{abstract}
In this paper, a simple dynamic part assignment (DPA) procedure is introduced and its effects on the performance of cellular manufacturing systems is evaluated. In this procedure rerouting of parts among machine cells is allowed for better machine utilization. Three data sets are used to compare the performance of manufacturing systems under job shop and cellular manufacturing when DPA is employed. The results of simulation runs indicate that the proposed DPA method improves the performance of cellular manufacturing significantly by reducing the congestion in machine cells with long waiting lines.
\end{abstract}

\section{INTRODUCTION}

Cellular manufacturing $(\mathrm{CM})$ is a proven technique in batch-type manufacturing. It improves the efficiency of manufacturing systems through reduction in set-up times, in-process inventories and throughput times. This has been shown in numerous successful cases of $\mathrm{CM}$ implementation $[7,9,19,20]$. Despite this, some studies suggest that the conversion from conventional batch-type manufacturing to cellular manufacturing may not always be beneficial. This is mostly due to the imbalanced workload on machines in machine cells which leads to the accumulation of inventories in front of bottleneck machines. Imbalanced workloads also cause under-utilization of non-bottleneck machines [3]. In addition, the organization of machines into dedicated machine cells decreases the flexibility in machine selection for the processing of parts [6]. Because of these problems, some researchers have questioned the superiority of $\mathrm{CM}$ to traditional job shop manufacturing.

A number of studies have been conducted to overcome the problem of bottleneck machines in $\mathrm{CM}$. In one study, the impact of sub-batch workload transfer on machine utilization in CM has been evaluated [15]. In another study, intercellular part transfer is proposed as an effective means of improving the efficiency of CM systems by directing the extra workloads from over-utilized machines to other cells [1]. Yet another approach to the problem of bottleneck machines is the development of alternative process plans and the rerouting of parts for increased scheduling flexibility [11]. Machine duplication [17], development of hybrid cells [16], and outsourcing [17] are other possible solutions to the bottleneck machine problem in cellular manufacturing systems.

As indicated above, flexibility in machine selection is one of the attributes of job shop systems where similar machines are grouped in departments. When such a system is converted to a cellular manufacturing system, that level of flexibility may no longer be available. This is due to the fact that, first, machines in each cell are dissimilar and, secondly, each cell is dedicated to process a part family. As a result, a machine in one cell may be over-utilized while a similar machine in another cell may be under-utilized. This can be overcome by allowing free flow of parts among machine cells at the cost of less effective group scheduling. Such a practice in its extreme is equivalent to going back to job shop manufacturing. Therefore, a compromise between the flexibility of part transfer among machine cells and the efficiency of independent machine cells seems to offer a reasonable solution to the problem of imbalanced workload in CM.

In this paper, a simple procedure for the rerouting of incoming parts to alternative cells is introduced. Such a procedure incorporates some flexibility into machine assignment in CM without significantly decreasing the effectiveness of group scheduling. While this procedure does not provide 
a complete solution to the problem of imbalanced machine workload in cellular manufacturing, it may improve the performance of a cellular manufacturing systems as will be demonstrated in the following sections.

\section{DYNAMIC PART ASSIGNMENT (DPA) METHOD}

The development of a cellular manufacturing system ideally results in the formation of independent machine cells. For the purpose of this study, these cells are referred to as primary cells. Jobs within a part family are normally processed in their primary cell. Any machine cell other than a primary cell capable of processing a job is considered as a secondary cell for that job. There may exist one or more secondary cells for a particular job.

The Dynamic Part Assignment method offers a mechanism for monitoring the workload of primary cells and assigning the new incoming job to a secondary cell if the workload in a primary cell exceeds a threshold value. Such a threshold value may be set by the shop supervisor to avoid long queues and to operate the cells in a relatively balanced condition.

Using the DPA approach, the workload of machine cells is examined whenever a new job arrives. Then the decision is made to assign new jobs to a secondary cell if necessary. This approach is expected to improve the performance of $\mathrm{CM}$ by reducing waiting time in machine cells.

To achieve this objective, the following factors are considered:

(a) A threshold value for cell congestion level is determined for each machine cell based on some criteria such as work-in-process storage capacity and job due date.

(b) To assign a job to a cell, priority is always given to the primary cell. The objective of this rule is to process a part family in its designated machine cell that has been configured during machine cell/part family formation process.

(c) Based on the cell congestion threshold value, if it is decided to assign a job to a secondary cell, the job will not be transferred to its primary cell. Similarly once a job is assigned to its primary cell it will not transfer to a secondary cell. Such constraints avoid the occurrence of new material handling between cells which may negatively impact CM performance [15].

Consider 2 machine cells as part of a large CM system (see Fig. 1(a)). Part family I consisting of part type A, B and C is assigned to its primary cell $I$. All three parts have common operation on machine type L. Cell II is considered as a secondary cell for part type A and B since the necessary
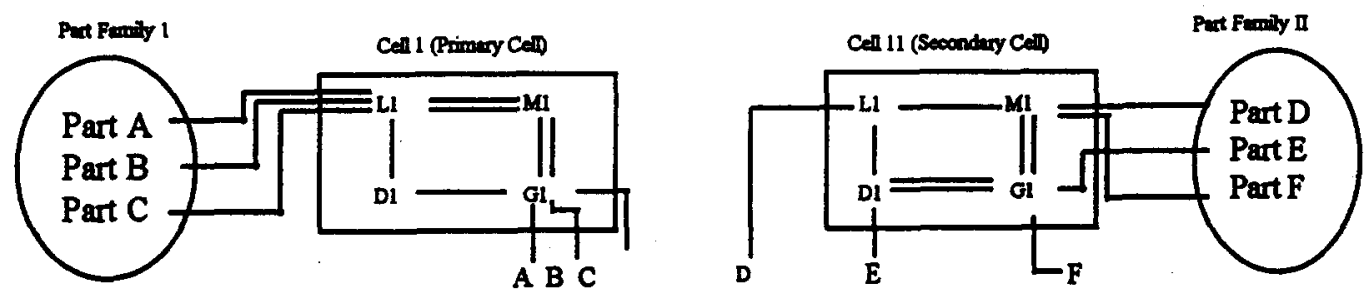

(a) No congetion in primary cell. All parts are procened in primary cell.

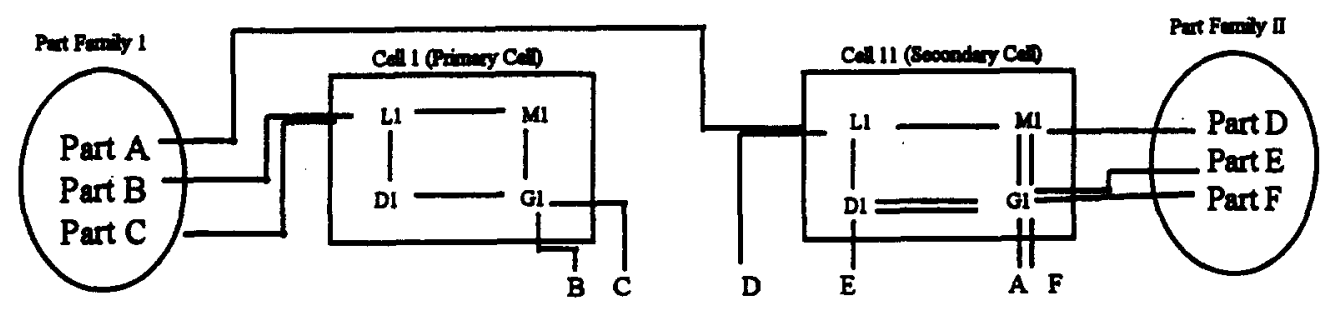

(b) One or more machines in primary cell are overtoadad. Part A is asaigad to a recondary cell.

Fig. 1. The DPA concept. 


$\begin{array}{ccccccccccccc}\text { Machines } & 1 & \mathbf{2} & \mathbf{3} & \mathbf{4} & \mathbf{5} & \mathbf{6} & \mathbf{7} & \mathbf{8} & \mathbf{9} & \mathbf{1 0} & \mathbf{1 1} & \mathbf{1 2} \\ \text { L1 } & & 1 & & & 1 & 1 & & & & 1 & 1 & 1 \\ \text { L2 } & 1 & & 1 & & & & 1 & & & & & \\ \text { L3 } & & & & 1 & & & & & 1 & & & \\ \text { M4 } & & 1 & & & & 1 & & & & 1 & 1 & 1 \\ \text { M5 } & 1 & & 1 & & & & 1 & & & & & \\ \text { M6 } & & & & 1 & & & & & 1 & & & \\ \text { D7 } & & 1 & & & 1 & 1 & & & & 1 & 1 & \\ \text { D8 } & 1 & & 1 & & & & & 1 & & & & \\ \text { D9 } & & & & & & & 1 & & & & 1\end{array}$

a. Machine-component matrix for first data set

\begin{tabular}{|l|c|c|c|}
\hline Department & $\mathbf{1}$ & $\mathbf{2}$ & $\mathbf{3}$ \\
\hline Machine Type & Lathe 1,2,3 & Mill 1, 2, 3 & Drill 1, 2,3 \\
\hline Quantity & $\mathbf{3}$ & 3 & 3 \\
\hline Part Assignment & $1,2,3,4,5,6,7,8,9$, & $1,2,3,4,5,6,7,9$, & $1,2,3,4,5,6,8,9$, \\
& $10,11,12$ & $10,11,12$ & 10,11 \\
\hline
\end{tabular}

b. Job shop configuration of first data set

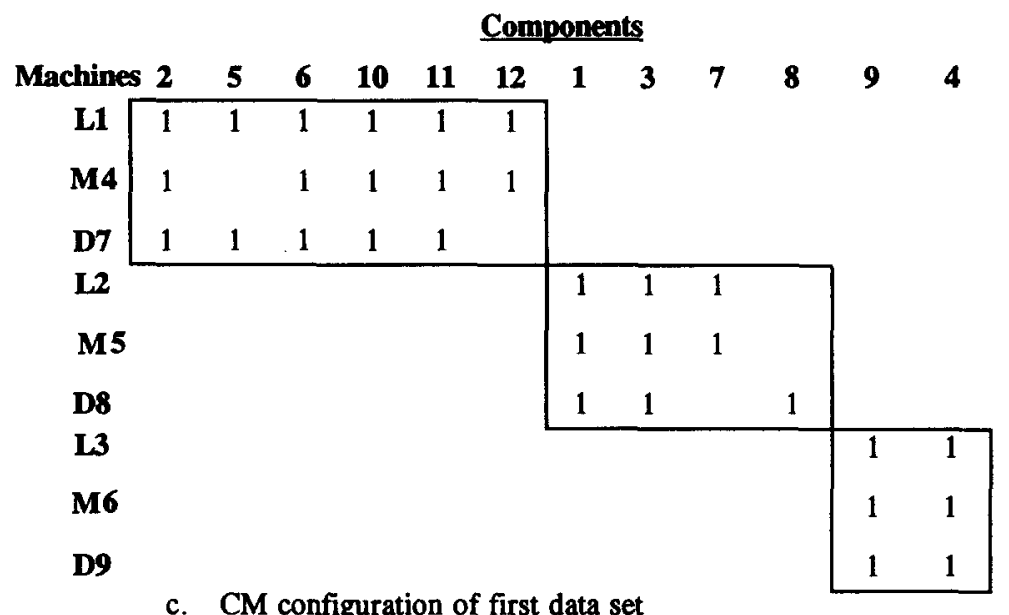

c. CM configuration of first data set

Fig. 2. (a) Machine-component matrix for first data set, (b) Job shop configuration of first data set, (c) $\mathrm{CM}$ configuration of first data set.

machine types to process these two parts are available in this cell (type $\mathrm{L}, \mathrm{M}$ and $\mathrm{G}$ ). This flow arrangement may create a congestion in the primary cell especially by machine type $L$. At some threshold level, the incoming part type A or B can be sent to the secondary cell which may be operated at a less machine utilization level (see Fig. 1(b)).

In order to evaluate the effect of the proposed method on the performance of $\mathrm{CM}$ cells, the following steps are taken:

Step 1. Define part families, form machine cells and assign part families to associated machine cells using one of the known machine-component grouping methods such as the Rank Order Clustering (ROC) algorithm [8], the Direct Clustering Algorithm (DCA) [2] or the Similarity Coefficient Method (SCM) [17].

Step 2. Develop the appropriate simulation model for the CM problem designed in Step 1 and for the equivalent job shop system [5]. 
Step 3. Run the simulation models developed in Step 2.

Step 4. Assign the new incoming parts to its primary machine cell if the level of congestion in the cell is below a threshold value. Otherwise, assign the part to a secondary cell.

Step 5. Compare the simulation results of the modified CM model in Step 4 with its equivalent job shop model using five performance measures: average flow time, average work-in-process (WIP) inventories, average machine utilization, average travelling distances, and average set-up times.

Step 6. Perform statistical analysis to determine the statistical significance of the differences between the performance of the CM system and its corresponding job shop system.

\section{NUMERICAL EXAMPLES}

Three machine-component matrices representing three different manufacturing systems are used to demonstrate the impact of the DPA procedure on the performance of a cellular manufacturing system. Simulation modeling is used to evaluate the performance of cellular manufacturing systems before and after the application of the DPA procedure and to compare the results with those of the corresponding job shop manufacturing systems. The paired- $t$ test is used to determine the statistical significance of the difference in the results in the two cases.

The data for the first example are given in Fig. 2. The second manufacturing system is presented in Fig. 3 and the third manufacturing system in Fig. 4.

\begin{tabular}{|l|c|c|c|c|c|}
\hline & Group 1 & Group 2 & Group 3 & Group 4 & Group 5 \\
\hline Machine Type: & Lathe & Mill & Grinder & Drill & Saw \\
\hline Quantity: & 2 & 3 & 4 & 4 & 2 \\
\hline $\begin{array}{l}\text { Part } \\
\text { Assignment: }\end{array}$ & $1,2,3,4,6$ & $2,3,4,5,6,7$ & $1,2,3,6,7$ & $2,4,5,9$ & $1,2,3$ \\
\hline
\end{tabular}

(a) Job shop configuration of second data set.

\section{Components}

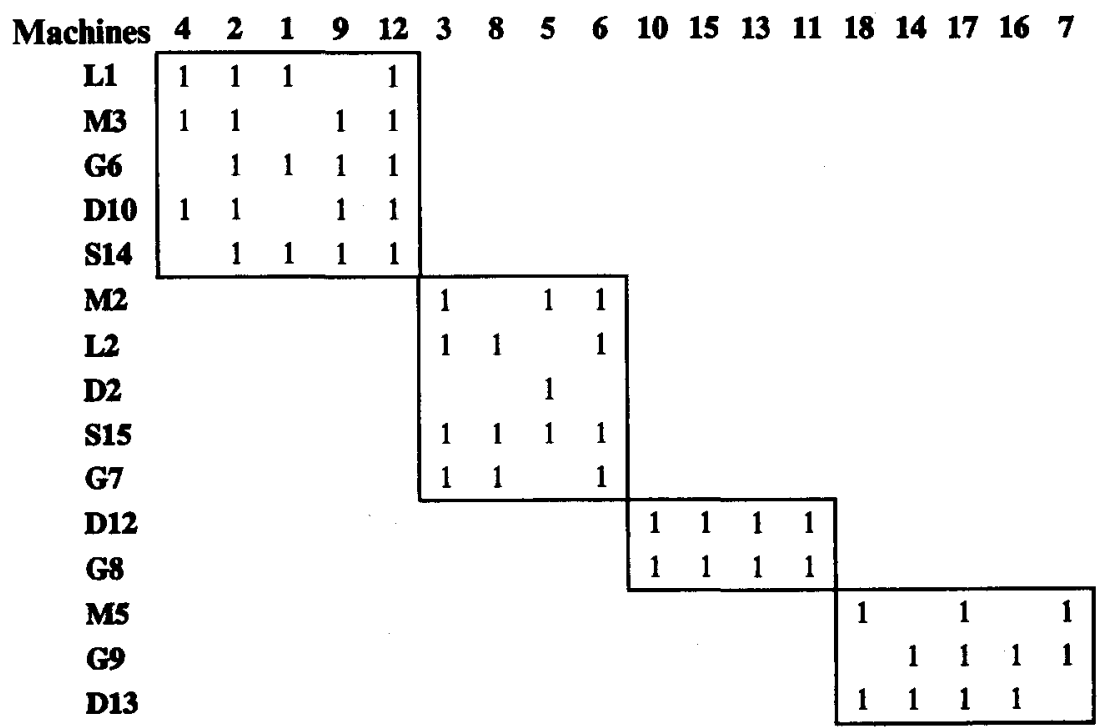

(b) $\mathrm{CM}$ configuration of second data set.

Fig. 3. (a) Job shop configuration of second data set, (b) CM configuration of second data set. 


\begin{tabular}{|l|c|c|c|c|c|c|c|c|c|c|}
\hline Department & 1 & 2 & 3 & 4 & 5 & 6 & 7 & 8 & 9 & 10 \\
\hline Machine Type: & 1 & 2 & 3 & 4 & 5 & 6 & 7 & 8 & 9 & 10 \\
\hline Quantity: & 3 & 4 & 3 & 3 & 3 & 3 & 4 & 4 & 4 & 5 \\
\hline $\begin{array}{l}\text { Part } \\
\text { Assignment: }\end{array}$ & 15,6 & 15,14 & 15,8 & 15,5 & 15,5 & 15,8 & 15,5 & 15,8 & 15,5 & 15,8 \\
\hline
\end{tabular}

(a) Job shop configuration of data set 3.

\section{Component}

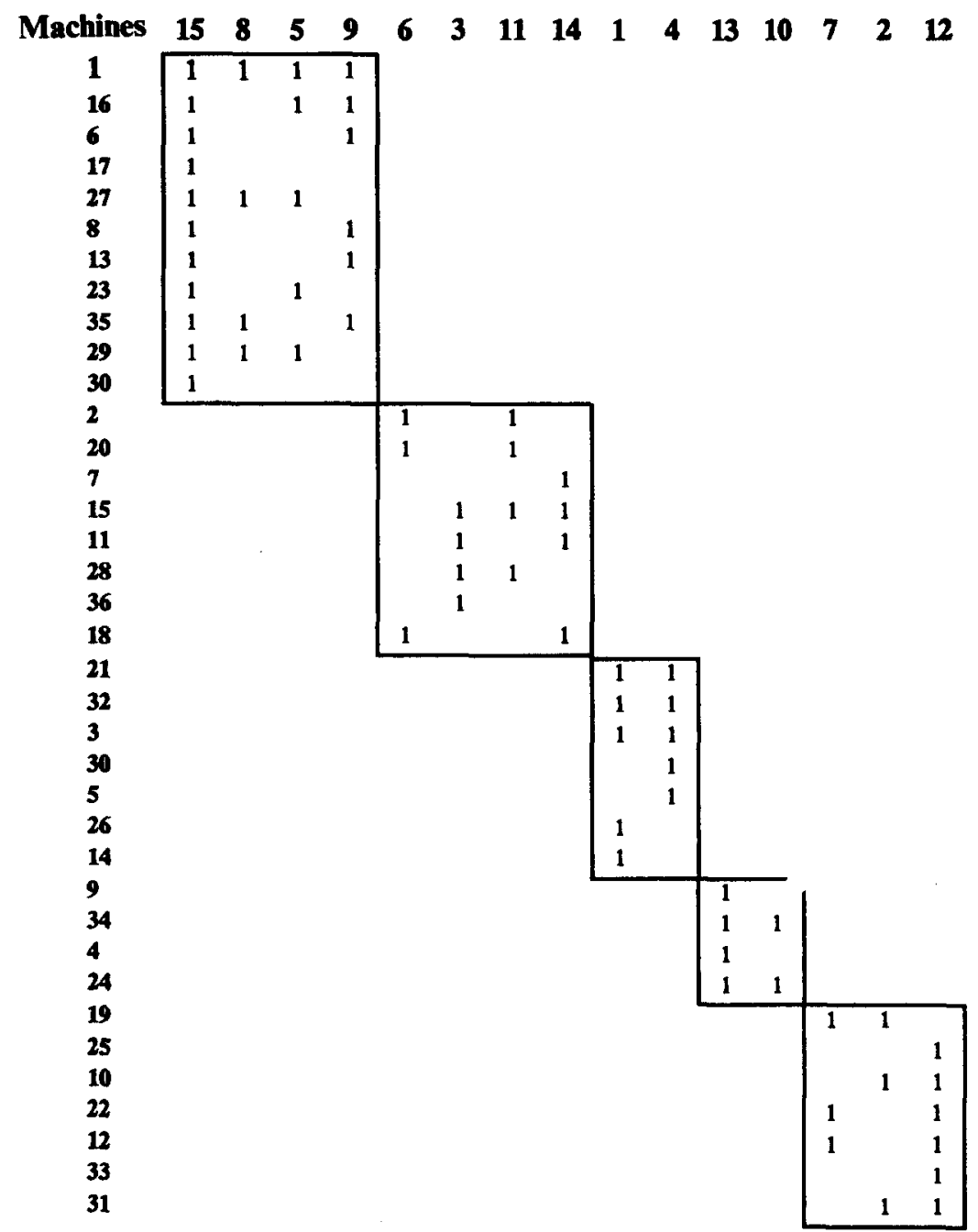

(b) CM configuration of data set 3.

Fig. 4. (a) Job shop configuration of third data set, (b) $\mathrm{CM}$ configuration of third data set.

\section{SIMULATION MODELS}

The simulation models of $\mathrm{CM}$ and functional facilities are coded in SIMAN in a discrete and process orientation manner in that the flow of parts through the machines in cells is described by the flow of entities. The processing time for all operations are exponentially distributed with means of 90 and 60 minutes for first and second data sets, respectively. The third data set is deterministic. The set-up times are assumed to be sequence dependent, that is, the amount of time required to 


\begin{tabular}{|c|c|c|c|c|c|c|}
\hline \multirow{2}{*}{ Data set } & $\begin{array}{c}\text { Facility } \\
\text { configuration }\end{array}$ & $\begin{array}{c}\text { Average } \\
\text { flow time } \\
\text { (min) }\end{array}$ & $\begin{array}{c}\text { A verage } \\
\text { WIP }\end{array}$ & $\begin{array}{c}\text { Average } \\
\text { machine } \\
\text { utilization }\end{array}$ & $\begin{array}{c}\text { Average } \\
\text { distance } \\
\text { traveled } \\
\text { (Ft) }\end{array}$ & $\begin{array}{c}\text { Average } \\
\text { setup time } \\
\text { (min) }\end{array}$ \\
\hline \multirow{3}{*}{1} & CM & $3256^{*}$ & $92^{*}$ & $58 \%^{*}$ & $21^{*}$ & $24.3^{*}$ \\
\cline { 2 - 7 } & $\begin{array}{c}\text { CM } \\
\text { with DPA } \\
\text { method }\end{array}$ & 1877 & 46 & $74 \%$ & 18.4 & 23.7 \\
\cline { 2 - 8 } & Job shop & 2538 & 64 & $74 \%$ & 90.6 & 33.9 \\
\hline \multirow{3}{*}{2} & CM & $2201^{*}$ & $87^{*}$ & $36 \%^{*}$ & $26^{*}$ & $41^{*}$ \\
\cline { 2 - 8 } & $\begin{array}{c}\text { CM } \\
\text { with DPA }\end{array}$ & 1156 & 37 & $44 \%$ & 26.6 & 39.8 \\
\cline { 2 - 8 } & Job shop & 1718 & 57 & $45 \%$ & 128 & 58.43 \\
\hline \multirow{3}{*}{3} & CM & $80^{*}$ & $8^{*}$ & $38 \%^{*}$ & $59^{*}$ & $4.9^{*}$ \\
\cline { 2 - 8 } & $\begin{array}{c}\text { CM } \\
\text { with DPA }\end{array}$ & 54 & 2.9 & $43 \%$ & 62 & 4.6 \\
\cline { 2 - 8 } & Job shop & 64 & 3.5 & $47 \%$ & 102 & 9.5 \\
\hline
\end{tabular}

*Model does not reach to steady state without applying DPA method. Reflect outputs at saturation point.

Fig. 5. Summary of simulation outputs.

set-up a machine depends on the degree of similarity of previous and current parts in term of tooling requirements.

A modified version of the CM model is used to test the effect of the DPA rule. Whenever a new part arrives, the model checks the workload of machines in a designated primary cell and transfers the part to that cell or a secondary cell. Once a part is assigned to a cell, the first-in-first-out rule is used to select a part from the queues.

In the CM model, once a part is assigned to a cell it remains there until its last operation. In other words, no intercellular move or activity is allowed. In the job shop facility, the interdepartmental carts transport unit loads in batches. In the CM facility, the intracellular conveyors transport parts between machines. The transportation times are assumed to be proportional to the distance travelled.

\section{EXPERIMENTAL CONDITIONS}

In order to make an unbiased comparison between the two alternative configurations under study, both models are treated under similar conditions so that any observed differences in performances are due to differences in system configurations rather than experimental conditions.

\begin{tabular}{||c|c|c|c|c|c||}
\hline Data set & $\begin{array}{c}\text { Mean } \\
\text { difference } \\
\text { flow time \& } \\
95 \% \text { C.I. }\end{array}$ & $\begin{array}{c}\text { Mean } \\
\text { difference } \\
\text { WIP \& 95\% } \\
\text { C.I }\end{array}$ & $\begin{array}{c}\text { Mean } \\
\text { difference } \\
\text { machine } \\
\text { utilization \& } \\
\text { 95\% C.I. }\end{array}$ & $\begin{array}{c}\text { Mean } \\
\text { difference } \\
\text { distance } \\
\text { traveled \& } \\
\text { 95\% C.I. }\end{array}$ & $\begin{array}{c}\text { Mean } \\
\text { difference } \\
\text { setup time \& } \\
\text { 95\% C.I. }\end{array}$ \\
\hline 1 & 636 & 17.9 & $.16 \%$ & 72.3 & 10.3 \\
& $625-648$ & $17.5-18.2$ & $.10-.20$ & $72-72.5$ & $10.2-10.4$ \\
\hline 2 & 550 & 20.8 & $.013 \% *$ & 101 & 18 \\
& $476-624$ & $15.1-26.5$ & $-.003-.016$ & $99.1-103$ & $17.3-18.7$ \\
\hline 3 & 10 & .5 & .04 & 41 & 5.1 \\
& $9.8-10.4$ & $.4-.53$ & $.03-.045$ & $38-43$ & $4.8-5.2$ \\
\hline
\end{tabular}

*Not gignificant at $=.05$

Fig. 6. Mean differences of measures of performance and their $95 \%$ confidence intervals. 
For example, the common random number technique [10] is used to block out any unwanted configuration differences by synchronizing input variables.

Since the systems start at empty state, a graphical procedure [10] is used to determine the length of warm-up period for deletion. In the CM model with the DPA method, the model reached the steady-state condition in 50 days and for the three data sets the simulation continued for 60 days under the steady-state condition. A similar approach was used to collect the data for the job shop model. However, the steady-state condition was not reached with the CM model without the DPA method. This observation supports the findings in Refs [3] and [6]. That is, the imbalance workload in $\mathrm{CM}$ may result in long queues in some machine cells.

The performance measures of interest include the average work-in-process inventory, average throughput time, average distance travelled, average set-up time and average machine utilization.

\section{ANALYSIS OF RESULTS}

The main objective of this study is to determine whether or not the performance of cellular manufacturing can be improved by incorporating the proposed DPA rule. The paired- $t$ confidence intervals have been formed for the differences between steady-state measures of performance of $\mathrm{CM}$ and job shop facilities. Fig. 5 shows the summary of simulation output for the three data sets. The average of differences in means and corresponding 95\% confidence intervals are presented in Fig. 6 . The results show that the CM model without the DPA rule results in large queues as well WIP as expected. This is mainly due to the congestion in some machine cells and the lack of any mechanism to redirect some of incoming parts to other cells with less workload.

It is evident from Figs 5 and 6 that the CM facility monitored under the proposed DPA method outperforms the job shop facility in all the data sets, and in all measures of performance except for machine utilization in which the difference is not significant in the first two cases. In addition, applying the DPA method has led to the relatively balanced queue length in machine type $L$ in all 3 cells in the first example. The examination of the part routings shows that machine type $L$ is always needed for first operation of most part types. In the CM facility, before applying the DPA method, this machine is rapidly overloaded in cell 1 because $50 \%$ of parts are routed to this cell. At the same time, the identical machine in cell 3 is under-utilized since only $12 \%$ of parts are routed there. After applying the DPA method, some of the incoming parts assigned to cell 1 are rerouted to cells 2 or 3 , resulting in a more balanced distribution of parts among the cells.

Similarly, in the second example, machine type $L$ in cell 1 is dedicated to 4 part types for their first operation, while the identical machine in cell 2 is dedicated to the first operation of only one part type. By anticipating the uneven flow of parts in the simulation model, a dramatic reduction in queue length in $\mathrm{CM}$ facility has been achieved.

In the third example, machines 1 and 34 were overloaded. After applying the DPA method, the workload of these two machines is shared with two similar machines ( 3 and 32 ) in cell 3 . As a result, the overall performance of cells were improved.

The improved set-up times and distance travelled in this study are consistent with the findings of previous research.

\section{CONCLUSION}

The proposed DPA method improved the performance of cellular manufacturing systems in this study. Based upon the three data sets considered, this research has shown that under equal experimental conditions, cellular manufacturing facility is superior to job shop facility if the workload and the level of congestion in machine cells is considered for the assignment of jobs to machine cells.

Applying the DPA method may not need extra supervisory effort since similar effort is needed in selecting a machine with minimum workload in job shop facility. In addition, rerouting the incoming parts to secondary cells does not violate the basic assumption of cell independency in CM since no intercellular moves are created in the DPA approach.

While cellular manufacturing and group technology are not always a better solution for an inefficient manufacturing facility, the methodology used in this study reveals the importance of 
considering alternate cell assignment based on the machine workload in future comparative studies in cellular manufacturing areas.

\section{REFERENCES}

1. C. P. Ang and P. C. Willey. A comparative study of the performance of pure and hybrid group technology manufacturing systems using computer simulation techniques. Int. J. Prod. Res. 22, 193-233 (1984).

2. H. M. Chan and D. A. Milner. Direct clustering algorithm for group formation in cellular manufacturing. J. Manuf. Syst. 1, 65-67 (1982).

3. P. D. Christy and S. N. Udayan. A simulation investigation of the design of group technology cells. Proceedings of Annual Meeting of the Decision Sciences Institute, 1201-1203 (1986).

4. F. G. Cummings. Simulation model to compare group technology and functional layout. Proceedings of Summer Simulation Conference, 626-630 (1980).

5. M. Djassemi. The use of machine-grouping efficiency in comparison of job shop and cellular manufacturing system: A simulation study. Unpublished Ph.D. dissertation, Department of Industrial and Manufacturing Engineering, University of Wisconsin-Milwaukee (1994).

6. B. B. Flynn and F. R. Jacobs. A simulation comparison of group technology with traditional job shop manufacturing. Int. J. Prod. Res. 24, 1171-1192 (1986).

7. N. L. Hyer. The potential of group technology for U.S. manufacturing. J. Oper. Manage. 4, 183-201 (1984).

7. J. R. King and V. Nakoranchai. Machine-component grouping in production flow analysis: An approach using rank order clustering algorithm. Int. J. Prod. Res. 18, 213-237 (1980).

9. D. O. Knight and M. L. Wall. Using group technology for improving communication and coordinating among teams of workers in manufacturing cells. Ind. Eng. 21, 28-34 (1989).

10. K. Law. Simulation Modeling and Analysis. McGraw-Hill Inc., New York (1991).

11. C. Mosier and L. Taube. The facets of group technology and their impacts on implementation-A state of art survey. Omega: Int. J. Mgmt Sci. 13, 381-391 (1985).

12. D. Rajamani, N. Singh and P. Aneja. Integrated design of cellular manufacturing systems in the presence of alternative process plans. Int. J. Prod. Res. 28, 1541-1554 (1990).

13. K. Rathmill and $R$. Leonard. The fundamental limitations of cellular manufacture when contrasted with the efficient functional layout. Proceedings of Int. Conference on Production Research, 523-546 (1987).

14. H. Sarper and D. M. Lane. Selection of the best production environment under a given job mix with probabilistic daily demands. Comput. Ind. Eng. 17, 281-287 (1989).

15. F. Sasani. A simulation study on performance improvement of group technology cells. Int. J. Prod. Res. 28, 293-300 (1990).

16. H. Seifoddini. Duplication process in machine cells formation in group technology. IIE Trans. 21, 382-388 (1989).

17. H. Seifoddini. Performance evaluation of hybrid cells in cellular manufacturing systems. IIE Trans. 24, 84-88 (1992).

18. H. Seifoddini and M. P. Wolf. Application of the similarity coefficient method in machine cells formation in group technology. IIE Trans. 18, 271-277 (1986).

19. S. Shafer and J. Meredith. A comparison of selected manufacturing cell formation techniques. Int. J. Prod. Res. 28, $661-673(1990)$.

20. N. C. Suresh and J. R. Meredith. Achieving factory automation through group technology principles. J. Oper. Manage. 5, 151-167 (1985).

21. H. A. Welke and J. Overbreeke. Cellular manufacturing: A good technique for implementing just-in-time and total quality control. Ind. Eng. 20, 36-41 (1988) 